\title{
ADDITIONAL OBSERVATIONS OF THE BARRED OWL IN ALBERTA
}

PETER C. BOXALL, Alberta Fish and Wildlife Division, Main Floor, North Tower, Petroleum Plaza, 9945 - 108 Street, Edmonton, Alberta. T5K 2 G6

Previous reports on the distribution of Barred Owls in Alberta have suggested a recent expansion into western North America. ${ }^{3} \quad 8 \quad 9$ In Alberta, Barred Owls seem to be restricted to mixedwood boreal forest and mature foothill forests in the southern portion of the province.' Numbers of this species are hypothesised to be increasing largely due to an increased tolerance of forests of a predominantly coniferous character. This selection of habitats in western North America is contrary to its preference for deciduous or mixed transitional forest in eastern North America. ${ }^{7} 2$ This report documents further records of the Barred Owl in Alberta and serves to update an earlier paper. The majority of these recent records were gathered from the Alberta Fish and Wildlife Division's Occurrence reporting system. This system developed and operated by the Enforcement - Field Services Branch, is called the Animal Incident Documentation System (A.I.D.S.). It is used to document observations of rare species, wildlife species found dead, various forms of humanwildlife interactions (e.g. bear attacks), and illegal activity pertaining to wildlife. This system has been in operation since April 1982. Additional records of Barred Owls were gathered from Christmas Bird Counts, and casual reports from naturalists.

Fifteen Barred Owl specimens have been turned into the Fish and Wildlife Division .(Table 1). Another eight owls were given to the Division with no locations provided. Of the 23 specimens, 19 were simply found dead by officers or citizens; 3 were injured and subsequently died and one owl was orphaned and did not survive to independence.

The geographical distribution of the records in Table 1 is similar to those reported by Boxall and Stepney, with the exception of one owl found near Coronation. ${ }^{1}$ This particular bird was found dead in the prairie-parkland ecotone during winter and may have been moving widely in search of food before starving to death or possibly being killed by an automobile. The cause of death for this owl was unknown. All of the other records fall within the montane-foothill region or the mixedwood boreal forest.

The possible expansion of this species southward through the mountain and foothill areas of Alberta is supported by an increase of recent records from the southwestern portion of the province. ${ }^{1}$ The Fish and Wildlife Division obtained owls which were found near Morley and Calgary (Table 1). Naturalists have reported other sightings of Barred Owls from Morley, Calgary and Bryant Creek in 1982; the Wildlife Reserve of Western Canada near Cochrane in 1983; and Calgary in 1984.465 Prior to 1980 I found only 12 records of this species south of Jasper National Park. ${ }^{1}$

Naturalists also reported observing Barred Owls around Grande Prairie and Edson. 510

Of all owls reported or turned in to the Alberta Fish and Wildlife Division, Barred Owls were the second fewest in 
Table 1. BARRED OWL RECORDS FORM THE ALBERTA FISH AND WILDLIFE DIVISION'S ANIMAL INCIDENT DOCUMENTATION SYSTEM APRIL 1982 TO APRIL 1985

Date

10 September 1982

1 December 1982

9 February 1983

3 March 1983

9 June 1983

30 June 1983

19 July 1983

15 December 1983

4 January 1984

10 February 1984

4 April 1984

6 December 1984

15 January 1985

24 January 1985

19 March 1985
Location

Grande Cache
Fox Creek
Fox Creek
Slave Lake
Edmonton
St. Albert
Morley
Grovedale
Calgary
Coronation
Niton Junction
Rocky Mountain House
Fox Creek
Brule
Whitecourt

An additional eight owls were turned in without locations.

TOTAL $\quad 15+8=23$

number (Table 2). Only the Northern Pygmy Owl was reported less often over the 3-year period. Over 142 times as many Great Horned Owls were reported and about 10 times as many Snowy, Great Gray and Short-eared owls were reported.

Records of the Barred Owl in Alberta are still required in order to define its range. There is no doubt that it is one of the rarest owls in the province despite its large size and characteristic vocal behavior.

I thank Laverne Smith for assisting me with locating published records of this species.

'BOXALL, P.C. and P.H.R. STEPNEY. 1982. The distribution and status of the Barred Owl in Alberta. Can. Field-Nat. 96:46-50

2 GODFREY, W.E. 1966. The birds of Canada. National Mus. of Can. Bull. No. 203.
${ }^{3}$ GRANT, J. 1966. The Barred Owl in British Columbia. Murrelet 47:39-45.

4 HARRIS, W.C. 1983. Prairie Provinces region. Am. Birds 37:192-194.

${ }^{5}$ HARRIS, W.C. 1984. Prairie Provinces region. Am. Birds 38:214-216.

6 HEILBRUN, L.H. and CBC REGIONAL EDITORS. 1983. The 1983 Audubon Christmas Bird Count. Count No. 157. Am. Birds 37:438.

7 NICHOLLS, T.H. and D.W. WARNER. 1972. Barred Owl habitat use as determined by radiotelemetry. J. Wildl. Mgmt. 36:213-224.

8 SHEA, D.S. 1974. Barred Owl records in western Montana. Condor 76:222.

9 TAYLOR, A.L. and E.D. FORSMAN. 1976. Recent range extensions of the Barred OWl in western North America, including the first records for Oregon. Condor 78:560-561.

10 YOUNG, V. 1984. Alberta Christmas Bird Counts - 1983. Alberta Naturalist 14:91-96. 
Table 2. NUMBER OF SPECIMENS AND/OR REPORTS OF OWLS TO FISH AND WILDLIFE DIVISION, ALBERTA

Owl Species

$\begin{array}{lrrrr} & 1982 / 83^{*} & 1983 / 84 & 1984 / 85 & \text { Total } \\ \text { Great Horned } & & & & \\ \text { Snowy } & 722 & 1,402 & 1,143 & 3,267 \\ \text { Great Gray } & 63 & 62 & 120 & 245 \\ \text { Short-eared } & 101 & 74 & 56 & 231 \\ \text { Saw-Whet } & 65 & 69 & 87 & 221 \\ \text { Long-eared } & 26 & 26 & 35 & 87 \\ \text { Hawk } & 23 & 20 & 39 & 82 \\ \text { Burrowing } & 16 & 13 & 19 & 48 \\ \text { Boreal } & 8 & 14 & 11 & 33 \\ \text { Barred } & 10 & 7 & 15 & 32 \\ \text { Pygmy } & 7 & 10 & 6 & 23 \\ & 1 & 6 & 3 & 10\end{array}$

* Fiscal years 1 April to 31 March

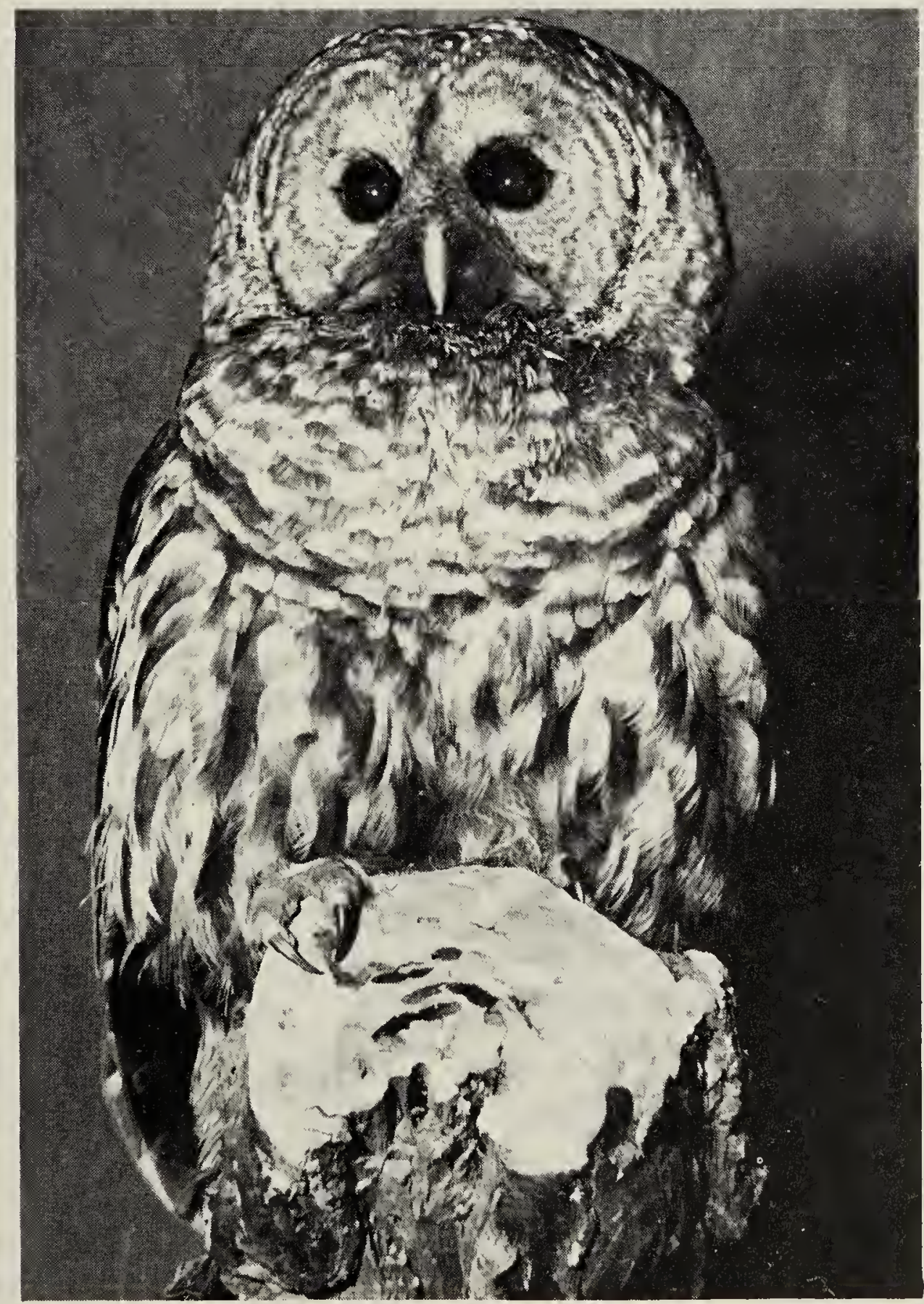

